\title{
An Overview of Opportunities for Waste Heat Recovery and Thermal Integration in the Primary Aluminum Industry
}

\author{
CASSANDRE NOWICKI $^{1}$ and LOUIS GOSSELIN ${ }^{1,2}$ \\ 1.-Department of Mechanical Engineering, Université Laval, Quebec City, QC G1V 0A6, Canada. \\ 2.—e-mail: Louis.Gosselin@gmc.ulaval.ca
}

Efficient smelters currently consume roughly $13 \mathrm{MWh}$ of electricity per ton of aluminum, while roughly half of that energy is lost as thermal waste. Although waste heat is abundant, current thermal integration in primary aluminum facilities remains limited. This is due to both the low quality of waste heat available and the shortage of potential uses within reasonable distance of identified waste heat sources. In this article, we present a mapping of both heat dissipation processes and heat demands around a sample facility (Alcoa Deschambault Quebec smelter). Our primary aim is to report opportunities for heat recovery and integration in the primary aluminum industry. We consider potential heat-to-sink pairings individually and assess their thermodynamic potential for producing energy savings.

\section{INTRODUCTION}

Thanks to its unique combination of properties (e.g., resistance to corrosion, ductility, light weight, high thermal and electrical conductivities, recyclability, etc.), aluminum is widely used in several sectors such as building components, transportation, packaging, power lines, and so on. In 2011, 43 million tons of primary aluminum were produced around the world, mostly in China (18 million tons), Russia (4 million tons), and Canada (3 million tons). ${ }^{1}$

The Hall-Héroult process, which is currently used to produce primary aluminum, is extremely energy intensive. Producing 1 ton of aluminum requires $15 \mathrm{MWh}$ of electricity on average and $12 \mathrm{MWh}$ for state-of-the art smelters. ${ }^{1,2}$ Additionally, fuels such as natural gas are used to provide heat in different processes and plant sectors. Ultimately, roughly half of the overall energy input is dissipated or lost to the atmosphere (waste heat). Knowing that energy costs account for approximately $40 \%$ of the total production costs, ${ }^{3}$ it is clear that the recovery of waste heat and plant energy integration represent a great economical potential to reduce production cost and overall energy consumption of this industry. By energy integration, we refer to strategies enabling direct use of waste heat, or with heat pumps and heat engines.
Another reason for pushing toward a better energy integration is the potential of this approach to reduce greenhouse gas emissions of smelters. Depending on the energy resources that are used to generate the electricity that is used in the pots, emissions between 0.03 (hydroelectricity) and 20 (coal) tons $\mathrm{CO}_{2} \mathrm{e} /$ ton $\mathrm{Al}$ are associated solely with the smelters electricity consumption. ${ }^{4}$ Moreover, the combustion of fuels in the plant also generates additional $\mathrm{CO}_{2}$. Therefore, reducing energy consumption reduces equivalent $\mathrm{CO}_{2}$ emissions.

Although waste heat is abundant in primary production plants, opportunities for thermal integration remain limited. Among the main reasons impeding waste heat recovery and thermal integration in smelters are the low quality of the waste heat (i.e., low temperature) and the large distances between heat sources and locations where heat could be used (herein called heat sinks). Furthermore, due to the transient behavior of some of the heat transfer processes, the availability of waste heat and demand for heat is not always synchronized.

The objectives of the present paper are as follows:

1. To offer an overview of the different waste heat sources in a typical primary aluminum plant, along with an overview of the different heat sinks. In other words, this first objective consists in presenting a plant-wide heat inventory. 
2. To highlight the best or more promising pairings between waste heat sources and heat sinks, and to provide a better understanding of the overall thermal integration potential in primary aluminum plants. It is important to mention that the scope of this article is not to study the economical feasibility of the different energy integration strategies that are presented but rather to study their thermodynamics feasibility.

It is obvious that all primary aluminum production facilities are different. Each plant might have different processes, pot technologies, anode baking furnaces, energy consumption rates, productivities, plant layouts, climates, raw material supplies, etc. This means that although all plants share similar features in terms of waste heat, the exact heat inventory and energy integration potential are likely to be, at least partly, plant dependent.

Rather than considering a "theoretical" plant that would have had little interest to the readers, it was decided to apply the analysis to a "real" plant. The primary aluminum facility that is considered in this article is the Alcoa Deschambault Quebec (ADQ) smelter, located in Canada $\left(46.65^{\circ} \mathrm{N},-71.93^{\circ} \mathrm{W}\right)$. ADQ produces close to 260,000 ton $\mathrm{Al} /$ year with 264 AP30 pot cells. Hydroelectricity is the main source of electricity for the plant and potline consumption is roughly $13 \mathrm{MWh} /$ ton $\mathrm{Al}$. ADQ produces its own prebaked anodes with open top ring furnaces, but does not refine bauxite on site.

\section{HEAT INVENTORY}

Although the electrolytic reduction process is responsible for the largest thermal waste, heat dissipation exists in other sectors of the plant as well. Both the anode baking and the casting are responsible for the generation of important thermal wastes. Additionally, the production of compressed air for mechanical applications throughout the plant is responsible for a significant amount of dissipated heat as well. Consequently, all four sectors are considered in our analysis. The waste heat sources identified in these sectors are discussed first. Annual heat loss values are given as a preliminary assessment of waste heat availability within the ADQ plant. Since all the amount of heat lost is unlikely to be fully recoverable, the values of "extractable" heat at each source are provided with reference to experimental studies when possible. Assumptions are made when such studies are not available. Furthermore, heat loss values are referenced with respect to a reference temperature of $25^{\circ} \mathrm{C}$. The identification of potential sinks for waste heat integration is reported next. The assessment includes existing space heating demands, process heat demands, as well as new demands that could be created. The evaluation of extractable heat at sources together with the identification of potential sinks will be used to examine source-to-sink pairing possibilities in the next section. An overview of annual heat loss at sources and annual heat demand at sinks is proposed in Fig. 1. The information concerning the temperature of the heat available/ required at each source/sink also appears in this figure.

\section{Waste Heat Sources}

In the potlines, we identify two distinct sources of thermal waste: the exhaust gas flow and the surface

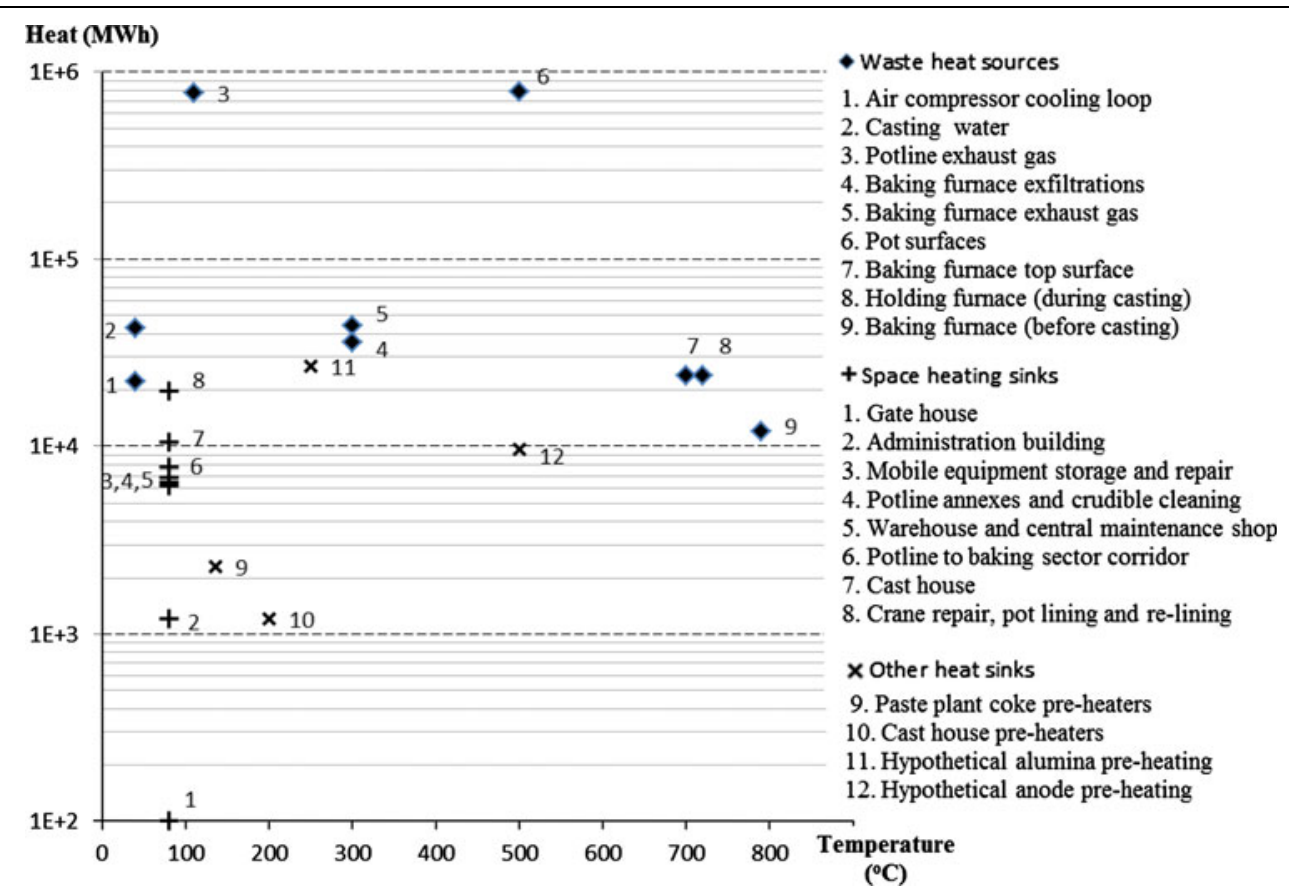

Fig. 1. Annual heat loss at waste heat sources and annual demands at heat sinks (ADQ smelter). 
heat flux. The exhaust gases consist mainly of the $\mathrm{CO}_{2}$ released from the Hall-Héroult process, which is largely diluted in air that infiltrates from the different gaps in the hoods above the electrolytic cells. This flow is collected by ducts from all cells and transported to a gas treatment center, before being discharged in the atmosphere. The exhaust gas carries about 3.0 MWh of heat per ton of aluminum produced. For $\mathrm{ADQ}$, this represents roughly $770,000 \mathrm{MWh}$ a year, or $88 \mathrm{MW}$ of continuous heat loss. In practice, the exact temperature of the exhaust changes depending on exterior air temperature, approximately from $100^{\circ} \mathrm{C}$ to $120^{\circ} \mathrm{C}$. Heat recovery before gas treatment allows access to higher gas temperatures in general $\left(110^{\circ} \mathrm{C}\right.$ on average), and cooling the exhaust gas before gas treatment is beneficial to the scrubbing system's performance, particularly in the summer. However, because contaminants and particles can be present in the exhaust flow, careful heat exchanger design is necessary to maintain reasonable fouling rates. Nevertheless, experimental studies at the 270,000 ton $\mathrm{Al} /$ year Nordural smelter (Iceland) have suggested that up to $55 \mathrm{MW}$ of heat could be recovered from potline exhaust gas (enough to supply 16,000 homes in a nearby community). ${ }^{5}$ It seems reasonable to assume that $40 \mathrm{MW}$ of heat, or roughly $350,000 \mathrm{MWh}$ a year, could be recovered from $\mathrm{ADQ}$ potline exhaust gas before the scrubbing system.

Pot surface heat losses represent about 3.0 MWh per ton of aluminum produced. This is roughly $89 \mathrm{MW}$ of continuous heat or $780,000 \mathrm{MWh}$ a year for $\mathrm{ADQ}$ potlines. Currently, this heat is dissipated in the potroom environment, and eventually it is released to the atmosphere. The extent to which we can access this energy is limited due to a complex balance that must be maintained inside the pots. However, a sidewall heat exchanger (SHE) design has been developed in Ref. 6 , in particular in view of implementing a power modulation strategy. Clean air circulates in this SHE and collects some of the sidewall heat flux. Research has shown that air temperature varying between $150^{\circ} \mathrm{C}$ and $200^{\circ} \mathrm{C}$ can be achieved. With an adequate number of SHEs, $0.05 \mathrm{MW}$ of heat per pot could thus be recovered. ${ }^{6}$ For ADQ, this is over $13 \mathrm{MW}$ of continuous heat or 116,000 MWh yearly. If these SHEs were installed primarily for power modulation, then the temperature and amount of heat available in the airflow will change in time.

In the anode baking sector, thermal waste exists in the form of exhaust gas, exfiltrations, and surface heat flux. At the ADQ plant, baking furnace exhaust gas carries roughly 5.0 MW of continuous heat, or $44,000 \mathrm{MWh}$ a year, at a temperature approaching $300^{\circ} \mathrm{C}$. These gases are essentially combustion products generated in the furnace. Concerns regarding heat exchanger fouling rates that apply to heat recovery in potline exhaust also apply to heat recovery in baking furnace exhaust. In this case, however, the heat quality is higher; even after gas treatment, the temperature remains over $250^{\circ} \mathrm{C}$. No experimental studies have been found on the evaluation of the amount of extractable heat in baking furnace exhaust gas, but we expect that $3 \mathrm{MW}$ of heat at $250^{\circ} \mathrm{C}$ is extractable for thermal integration purposes, with adequately designed heat exchangers (i.e., heat exchange efficiently of $\sim 60 \%$ ). Furthermore, there is a potential to increase the amount of extractable heat in furnace exhaust ducts using exfiltration air. The air that exfiltrates from the different furnace sections is comparatively very clean (it contains no combustion products or unburned residues) since it originates from the anode cooling sections of the furnace. ADQ furnace exfiltration air carries off a total of about $4.1 \mathrm{MW}$ of continuous heat, or $36,000 \mathrm{MWh}$ a year. This air is released at different temperatures along the furnace, varying between $60^{\circ} \mathrm{C}$ and $1200^{\circ} \mathrm{C}$. Exfiltration temperature and flow rate data from individual furnace sections was not available for $\mathrm{ADQ}$. Considering the temperature and flow rate values reported in Ref. 7 , it is concluded that if exfiltrations could be channeled in a single stream, then exfiltration heat could be available for thermal integration in the form of an airflow at $\sim 300^{\circ} \mathrm{C}$. The amount of easily extractable heat is difficult to estimate since present furnaces are not designed to channel exfiltrations into a single stream; exfiltrations are currently dissipated into the surroundings. However, installing exhaust ramps in the anode cooling sections of the baking furnace to feed exfiltration air into the main flue gas duct could increase the amount of waste heat available in the exhaust without the need to install additional ducts. $^{8}$ We expect that an additional $2 \mathrm{MW}$ of continuous heat could be extracted from furnace exhaust if such a measure was implemented.

Baking furnace boundary heat flux is most important at the furnace top surface (top of coke layer and top of fluewall). In the case of the ADQ plant, this heat flux is responsible for roughly 2.7 MW of continuous heat loss or 24,000 MWh a year. Similar to exfiltration temperatures, top surface temperatures vary with furnace sections (between $100^{\circ} \mathrm{C}$ and $1100^{\circ} \mathrm{C}$ ) based on Ref. 7. Using temperature and heat flux data from individual furnace sections, an average temperature of $700^{\circ} \mathrm{C}$ is obtained for this heat source. However, further research is required to assess how much of the heat released from the furnace top boundary could potentially be recovered with adequate technology. We do not make an assumption with regards to extractable heat for this waste heat source since the best energy efficiency initiatives might be associated with furnace design alternatives that reduce this heat flux altogether. ${ }^{7}$

In the cast house, high-temperature thermal waste originates from holding furnaces. The molten aluminum load first arrives to the ADQ cast house too hot for casting to begin (at about $860^{\circ} \mathrm{C}$ ), and it is 
left to cool in ambient air until it reaches a $720^{\circ} \mathrm{C}$ temperature. Furnace doors are left wide open during this time, and a lot of the aluminum heat is dissipated into the cast house environment instead of through the chimneys. Roughly 12,000 MWh a year of high-quality, high-temperature heat is released during the wait $(0.05 \mathrm{MWh}$ per ton of aluminum). Once the adequate temperature is reached, the furnace doors are closed and casting begins. Fuel burners are used intermittently to keep the aluminum load at the casting temperature. Another $24,000 \mathrm{MWh}$ of waste heat a year is generated during this period (0.09 MWh per ton of aluminum). In this case, most of the heat is expected to be released through the furnace chimneys.

Overall, holding furnace chimneys transit a significant amount of heat and they might transit even more heat if some of the heat that is currently dissipated directly to the cast house environment could be redirected into the chimneys. Moreover, because 10 casting operations are conducted within a 24-h day, and since each casting lasts $90 \mathrm{~min}$, there are casting operations taking place throughout the day. For this reason, the waste heat availability can be considered roughly continuous at $4.2 \mathrm{MW}$. At a chimney's base, this heat is available at about $600^{\circ} \mathrm{C}$ according to $\mathrm{ADQ}$ data. We assume that at least $2 \mathrm{MW}$ of heat are extractable for thermal integration purposes (i.e., a heat exchange efficiency of $50 \%)$.

In addition to a holding furnaces' chimneys, the cooling water used in casting pits of the ADQ cast house is also identified as an important waste heat source. It carries off about $4.9 \mathrm{MW}$ of roughly continuous heat at an average temperature of $40^{\circ} \mathrm{C}$. This accounts for 43,000 MWh of heat lost yearly. In this case, because the heat is already contained in water, the entire $4.9 \mathrm{MW}$ can be considered as extractable heat. The same can be said about the heat that is contained in the glycol/water loop that serves in cooling air compressors. Five air compressors function continuously at the $\mathrm{ADQ}$ facility (these are located in the compressed air building). This is another $2.5 \mathrm{MW}$ of continuous heat $\left(22,000 \mathrm{MWh}\right.$ a year) at about $40^{\circ} \mathrm{C}$.

\section{Heat Sinks}

Eight space-heating sinks have been identified at the ADQ plant. These are listed in Table I, which also gives the approximate distances to the four sectors of the facility where waste heat sources have been identified. The annual space heating requirements vary between $100 \mathrm{MWh}$ for the gate house to 19,600 MWh for the crane repair, lining, and relining building (individual demands can be obtained from Fig. 1). Currently, space heating is mostly provided by natural gas. We assume that water at $80^{\circ} \mathrm{C}$ is required for the heating system. Although incorporating space-heating sinks into Fig. 1 allows us to quickly understand the relative size of these sinks (and the annual heating costs that are associated), care should be taken in comparing these demands to the availabilities at source points. In fact, since outside temperature varies greatly throughout the year, space-heating demands should be understood on a monthly basis rather than as yearly values. The ratio of monthly heat degree days to annual heat degree days for the Deschambault region (obtained from 2005 weather records) indicates that $20 \%$ of the annual space heating demand occurs in the month of January. In other words,

Table I. Approximate distances separating sinks from sources at the ADQ plant

\begin{tabular}{|c|c|c|c|c|}
\hline \multirow[b]{2}{*}{ Sinks } & \multicolumn{4}{|c|}{ Sources } \\
\hline & Potlines & Baking Sector & Cast House & Compressed Air Sector \\
\hline \multicolumn{5}{|l|}{ Space heating } \\
\hline Gate house & $400 \mathrm{~m}$ & $300 \mathrm{~m}$ & $300 \mathrm{~m}$ & $300 \mathrm{~m}$ \\
\hline Administration building & $400 \mathrm{~m}$ & $300 \mathrm{~m}$ & $200 \mathrm{~m}$ & $300 \mathrm{~m}$ \\
\hline Mobile equipment storage and repair & $200 \mathrm{~m}$ & $300 \mathrm{~m}$ & $150 \mathrm{~m}$ & $150 \mathrm{~m}$ \\
\hline Potline annexes and crucible cleaning & $150 \mathrm{~m}$ & $400 \mathrm{~m}$ & $200 \mathrm{~m}$ & $100 \mathrm{~m}$ \\
\hline Warehouse and central maintenance shop & $300 \mathrm{~m}$ & $300 \mathrm{~m}$ & $200 \mathrm{~m}$ & $200 \mathrm{~m}$ \\
\hline Corridor connecting potlines & $100-200 \mathrm{~m}$ & $100-200 \mathrm{~m}$ & $300-400 \mathrm{~m}$ & $300-400 \mathrm{~m}$ \\
\hline $\begin{array}{l}\text { and baking sector } \\
\text { Cast house }\end{array}$ & $300 \mathrm{~m}$ & $500 \mathrm{~m}$ & $0 \mathrm{~m}$ & $150 \mathrm{~m}$ \\
\hline $\begin{array}{l}\text { Crane repair, pot lining, } \\
\text { and relining building }\end{array}$ & $200 \mathrm{~m}$ & $500 \mathrm{~m}$ & $400 \mathrm{~m}$ & $300 \mathrm{~m}$ \\
\hline \multicolumn{5}{|l|}{ Process input preheating } \\
\hline Coke preheating & $200 \mathrm{~m}$ & $200 \mathrm{~m}$ & $600 \mathrm{~m}$ & $600 \mathrm{~m}$ \\
\hline Scrap and alloys material preheating & $300 \mathrm{~m}$ & $500 \mathrm{~m}$ & $0 \mathrm{~m}$ & $100 \mathrm{~m}$ \\
\hline Cathode preheating & $200 \mathrm{~m}$ & $500 \mathrm{~m}$ & $400 \mathrm{~m}$ & $300 \mathrm{~m}$ \\
\hline Anode or alumina preheating ${ }^{\mathrm{a}}$ & $0-200 \mathrm{~m}$ & $200-700 \mathrm{~m}$ & $300-600 \mathrm{~m}$ & $300-600 \mathrm{~m}$ \\
\hline
\end{tabular}


even if on an annual basis the amount of waste heat seems sufficient to fulfill a space-heating duty, it is necessary to look at the heat transfer rate or power available at a given time because of large fluctuations of space heating demands.

In addition to buildings requiring space heating, material input preheaters have been identified as potential sinks for heat integration. In the case of the $\mathrm{ADQ}$ plant, a coke preheater in the paste plant, and scrap and alloy material preheaters in the cast house, have been considered. The preheater in the paste plant currently brings coke to a temperature of $135^{\circ} \mathrm{C}$ prior to mixing with other anode paste components. This requires $0.3 \mathrm{MW}$ of continuous heat or $2300 \mathrm{MWh}$ a year. This is currently achieved through hot oil heaters that use natural gas. The heat requirement of the scrap preheater and the alloy materials preheater that operate in the ADQ cast house is approximately $1200 \mathrm{MWh}$ a year. However the demand of these preheating furnaces is not continuous; it fluctuates between $0 \mathrm{MW}$ and 0.4 MW during the day. Scrap and alloy materials must be brought to a temperature of about $200^{\circ} \mathrm{C}$ by the preheating operation.

In addition to the aforementioned process input preheating demands, the preheating of alumina and/or anodes is considered as a possible way to reduce electrical energy consumption of potlines. Preheating alumina prior to injection into electrolytic cells can have beneficial effects on the dissolution rates in the cryolite bath, but the exact impacts on the pot performance is yet to be addressed. According to Ref. 9, these beneficial effects are observed for relatively high alumina temperatures, although some authors seem to believe that benefits are also beneficial at a lower preheating temperature. Here, we assumed that this initiative would demand preheating alumina to a temperature of at least $250^{\circ} \mathrm{C}$. Considering that 1.9 tons of alumina are consumed for every ton of aluminum produced, the associated heat requirement would be $0.10 \mathrm{MWh}$ per ton of aluminum, 26,800 MWh a year, or 3.1 MW of continuous heat.

Anode preheating prior to loading into electrolytic cells would also require relatively high temperatures. Experimental studies suggest that anode preheating to temperatures approaching $500^{\circ} \mathrm{C}$ at the anode bottom surface, and $200^{\circ} \mathrm{C}$ at the anode core, could reduce pot cell energy consumption by as much as 0.04 MWh per ton of aluminum produced, and increase current efficiency. ${ }^{10}$ From baked anode properties, we estimate that this sort of preheating would require roughly $0.04 \mathrm{MWh}$ per ton of aluminum, or $9700 \mathrm{MWh}$ yearly. This is equivalent to 1.1 MW of continuous high-temperature heat.

\section{HEAT INTEGRATION OPPORTUNITIES}

Thermodynamic limitations constrain sourceto-sink pairing possibilities in general. Source and sink temperatures will dictate whether direct heat exchange is possible or whether this exchange will require a heat pump (with power generation opportunities considered only for thermal waste of moderate to high temperature). Here, the opportunities for integrating waste heat within the ADQ facility are assessed by considering waste heat characteristics in juxtaposition to the demands of the sinks identified, as well as the distance between them. Figure 2 offers an overview of the extractable heat transfer rates at each source temperature and allows a comparison with demands at sinks. The

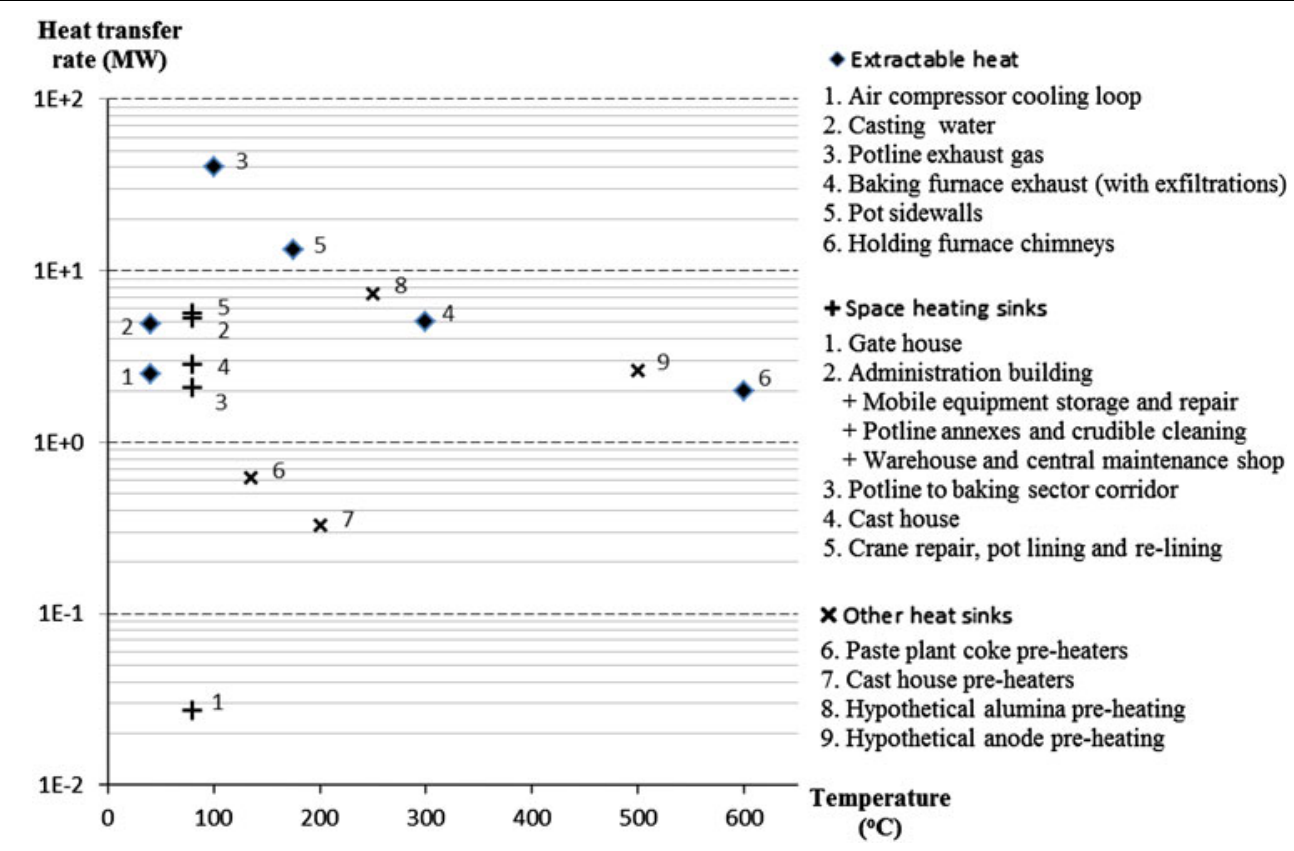

Fig. 2. Heat transfer rates extractable at waste heat sources and peek demands at heat sinks (ADQ smelter). 
possibility of selling heat outside of the plant boundaries will also be considered for otherwise nonusable waste heat. In evaluating monetary savings, we assume the cost of electricity to be $43 \$$ / $\mathrm{MWh}^{11}$ and the cost of natural gas to be $0.18 \$ / \mathrm{m}^{3}{ }^{12}$ with an $80 \%$ efficiency for the natural gas heating systems. Furthermore, for evaluating heat dissipation associated with heat transport from a source to a sink, we assume that ducts are poorly insulated (overall heat transfer coefficient $U$ of $10 \mathrm{~W} / \mathrm{m}^{2} \mathrm{~K}$ ). For simplicity, we assumed a linear heat loss proportional to the distance $d$ and driving temperature difference, i.e., $L=U d\left(T_{\text {source }}-T_{\infty}\right)$ [W], where $T_{\text {source }}$ and $T_{\infty}$ are the source and environment temperatures, respectively. This approach remains adequate as long as the heat losses are not too large.

The lowest quality heat that was identified in the primary aluminum facility is that of cooling water in the cast house and glycol/water in the compressor rooms. As mentioned, roughly $4.9 \mathrm{MW}$ of heat is available in the form of water at $40^{\circ} \mathrm{C}$ in the cast house and 2.5 MW in the form of water/glycol at $40^{\circ} \mathrm{C}$ in the compressor rooms.

A group of buildings (directly adjacent to one another) is found in the vicinity of both these waste heat sources. This group includes the administration building, the mobile equipment storage and repair building, the potline annexes and crucible cleaning building, and the warehouse and central maintenance shop. Together, these space-heating sinks consume over $20,800 \mathrm{MWh}$ a year and require an average of 5.7 MW of heat in January. The cast house space-heating requirement averages 2.9 MW in January. We estimate that transporting heat from the casting and compressed air sectors to the nearby group of buildings leads to about $0.1 \mathrm{MW}$ in transportation losses when outside temperature is $-18^{\circ} \mathrm{C}$ (the average minimum temperature in January). We conclude that the $40^{\circ} \mathrm{C}$ heat (from both casting water and compressor cooling loop) is abundant enough to satisfy the heating needs of the group of buildings mentioned above, as well as that of the cast house, most of the time; however, a backup system should still be available for supplemental heating when outside temperatures fall below $-10^{\circ} \mathrm{C}$. Assuming that heat pumps with a coefficient of performance of 4 are used, up to $2 \mathrm{MW}$ of electrical power would be needed to drive the heat pumps and $7600 \mathrm{MWh}$ annually. The savings associated with this heat integration opportunity is estimated as $\$ 0.3$ million a year and could reduce $\mathrm{CO}_{2}$ equivalent emissions by over 6000 tons since space heating is currently provided by natural gas $\left(1.9 \mathrm{~kg} \mathrm{CO} 2 \mathrm{e} / \mathrm{m}^{3}\right)$ and hydropower in Quebec is only associated with $\sim 2$ t CO$_{2} \mathrm{e} / \mathrm{MWh} .^{5}$

Next on the waste heat quality scale is the potline exhaust gas. Although the amount of heat extractable there is quite large (estimated at $40 \mathrm{MW}$ ), potential uses are limited since temperature is only about $100^{\circ} \mathrm{C}$ above ambient. With space heating needs for the facility as a whole averaging at about
$16 \mathrm{MW}$ in the month of January, there is enough heat available to fulfill all space-heating needs, with no heat pump required. This source of thermal waste is relatively central to the facility. Even with poorly insulated ducts, path losses associated with transporting heat to all space-heating clients will add-up to no more than 1 MW or 2 MW in January weather. Eliminating the need for natural gas in space heating would equate to over $\$ 1.2$ million in annual savings and to a reduction in $\mathrm{CO}_{2}$ emissions close to 12,000 tons. Nevertheless, a significant portion of the exhaust gas waste heat would still be available since the space-heating demand is much smaller than the heat contained in the exhaust gases.

Other possibilities for integrating potline exhaust gas heat include selling it outside of the facility or using it for load preheating or power generation. If incentives beyond waste heat recovery lead to the implementation of alumina and/or anode preheating systems, then exhaust gas heat, although not high enough to bring either of these to a satisfactory temperature, could be used to start off the preheating process. Alternatively, Organic Rankine Cycles (ORC) or Kalina cycles could be used to generate 4$7 \mathrm{MW}$ of power (assuming an efficiency of $10-20 \%$ ). ${ }^{13}$ However, these cycles may not be economically viable, and thus more research is needed. ${ }^{14}$

Heat recovery at pot sidewalls can give access to higher quality heat, but because of the careful tuning required to maintain the heat balance across the bath ledge, these measures are mostly considered in the context of power modulation initiatives. As discussed before, experimental studies reveal that this sort of initiative would allow access to $13 \mathrm{MW}$ of waste heat in the form of air at 150 $200^{\circ} \mathrm{C}$. Assuming that a heat engine with $20 \%$ efficiency is implemented, this is roughly $3 \mathrm{MW}$ of electricity that could be generated. Alternatively, the previous comment about alumina and/or anode preheating also applies here. If these measures are implemented, then pot surface heat could be used to start off the preheating.

The waste heat sources that have been identified in the baking sector are of relatively high quality. Combining both baking furnace exfiltration air and exhaust gases, we expect roughly $5 \mathrm{MW}$ of continuous heat at $250-300^{\circ} \mathrm{C}$ to be extractable. Assuming a heat engine efficiency of $30 \%$, only $1-2 \mathrm{MW}$ of power could be obtained from this waste heat source. This is about $\$ 0.6$ million a year worth of electricity for $\mathrm{ADQ}$, which may or may not justify investment costs. Alternatively, the waste heat could be used to preheat coke in the paste plant, which is relatively nearby. However, because about $0.4 \mathrm{MW}$ are sufficient for coke preheating, most of the heat would be left unused. Furthermore, the annual savings associated with this measure equate to no more than $\$ 0.06$ million in natural gas, which again may not justify investment costs.

The waste heat generated in the cast house holding furnaces is of high quality and could be suitable for 
generating power through a steam engine. Assuming that about $2 \mathrm{MW}$ is extractable, $1 \mathrm{MW}$ of power could be generated (assuming 50\% efficiency). However, because this is only worth about $\$ 0.4$ million a year in electricity savings, the economical interest is uncertain. Alternatively, scrap and alloy material preheating could be satisfied with the holding furnace waste heat. This would save $\$ 0.02$ million a year in natural gas consumption.

Finally, because our analysis estimates that there is about $40 \mathrm{MW}$ more extractable heat at sources than there are demands at sinks, there may be opportunities to use waste heat from the plant to satisfy some heat requirements outside the plant. For example, industries and buildings located in the vicinity of the smelter could potentially purchase the available heat. Several types of industries require low temperature heat such as greenhouses, textiles, cleaning facilities, etc. Also, depending on climate and localization, several "out of the plant" usages could be considered (e.g., desalinization of seawater, cooling with absorption cycles, residential district heating, etc.). To evaluate the transmission heat losses, it would be required to determine the exact location of these heat sinks outside of the plant.

\section{CONCLUSION}

Nearly 2 TWh of heat were found to be dissipated as thermal waste annually in the $\mathrm{ADQ}$ facility, but only $34 \%$ is easily extractable based on the literature. Although we chose to be rather conservative in our assumptions and proper system designs might allow access to a larger portion of the thermal waste, this illustrates the first major difficulty for waste heat recovery in the primary aluminum industry. Extracting the waste heat (capturing it in a heat transfer fluid) requires adapted heatexchanger designs. Similarly, there is a need for research into developing more efficient heat pumps and power generation cycles in different temperature ranges. Furthermore, without an assessment of implementation costs as well as a thorough evaluation of operational and maintenance costs, it is not possible to conclude which heat integration measure should be implemented in a particular facility. Restrictions in regards to acceptable return on investment make it difficult to implement energy efficiency measures that are not paid back within 3 or 4 years. Nevertheless, our analysis has allowed us to conclude that eliminating natural gas use associated with space heating demands is a feasible heat integration strategy thermodynamically. This would save $\$ 1.2$ million a year in natural gas bills and eliminate 12,000 tons of $\mathrm{CO}_{2}$ equivalent emissions. The potential to generate power with waste heat, in the scope of our rather conservative assumptions regarding extractable heat, is $\sim 10 \mathrm{MW}$ in the ADQ facility. This is assuming power generation efficiencies representative of current technology in the prescribed temperature ranges. Several options are possible and careful feasibility analysis is necessary to decide which measure is the most profitable.

Finally, it is important to note that processes themselves can be optimized so as to produce less thermal waste. Furthermore, plant layout can greatly facilitate heat integration; new smelters should be built with this in mind. Minimizing distances between the sinks and the sources that could satisfy their needs may largely increase the technical/economic feasibility of certain heat integration measures.

\section{ACKNOWLEDGEMENTS}

The authors' work is supported by the Fonds de Recherche Québec-Nature et Technologies (FRQNT). The authors thank Alcoa for its participation in this research.

\section{REFERENCES}

1. International Aluminum Institute, Current IAI Statistics, http://www.world-aluminium.org/Statistics/Current+statistics. Accessed 22 March 2012.

2. T. Allagh, Global Aluminum: 2012 Outlook, http://www.platts. com/NewsFeature/2012/aluminum/index. Accessed 22 March 2012.

3. Dialogue sur l'Aluminium, http://www.ledialoguesurlalumi nium.com/d\%C3\%A9veloppement-durable/1\%CA\%BCalumi nium-et-1\%CA\%BC\%C3\%A9nergie. Accessed 21 June 2012.

4. Office of Energy Efficiency, Natural Resources Canada, http://oee.nrcan.gc.ca/node/9166. Accessed 5 September 2011.

5. M. Fleer, Heat Recovery from Exhaust Gas of Aluminum Reduction Cells, Reyst 2010, http://en.ru.is/media/reyst/ Martin_Fleer.pdf. Accessed 11 May 2012.

6. S. Namboothiri, P. Lavoie, D. Cotton, and M.P. Taylor, Light Metals (Warrendale, PA: TMS, 2009), pp. 317-322.

7. D.S. Severo, V. Gusberti, and E.C.V. Pinto, Light Metals (Warrendale, PA: TMS, 2005), pp. 697-702.

8. W. Leisenberg, Light Metals (Warrendale, PA: TMS, 2006), pp. 621-624.

9. O. Kobbeltvedt, S. Roseth, and J. Thonstad, Light Metals (Warrendale, PA: TMS, 1996), pp. 421-427.

10. O. Fortini, S. Garminella, E. Kunn, Y. Ruan, B. Yacob, and J. Sorensen, Light Metals (Warrendale, PA: TMS, 2012), pp. 595-600.

11. D. Tremblay, Les Géants Engagés dans la Course aux Kilowattheures, May 2012, http://fr.canoe.ca/cgi-bin/imprimer. cgi?id=1107836. Accessed 17 May 2012.

12. Grandes Entreprises, Évolution du Prix du Gaz, Gaz Metro, May 2012, http://www.grandesentreprises.gazmetro.com/ prix-du-gaz/evolution-prix-du-gaz.aspx?culture=fr-ca. Accessed 17 May 2012.

13. U.S. Department of Energy, Waste Heat Recovery: Technology and Opportunities in U.S. Industry, Industrial Technologies Program, March 2008, http://www1.eere.energ y.gov/manufacturing/intensiveprocesses/pdfs/waste_heat_ recovery.pdf. Accessed 11 May 2012.

14. U.S. Department of Energy, Modifications and Optimization of the Organic Rankine Cycle: Improved Recovery of Waste Heat in Industrial Processes, Industrial Technologies Program, May 2011, http://www1.eere.energy.gov/manufacturing/ intensiveprocesses/pdfs/organic_rankine_cycle.pdf. Accessed 11 May 2012. 